\title{
Correction to: Late Silurian and Devonian ostracods of the Istanbul Zone (Western Pontides) and the Taurides: palaeogeographical implications
}

\author{
Atike Nazik ${ }^{1}$ (D) Helga Groos-Uffenorde ${ }^{2} \cdot$ Ewa Olempska $^{3} \cdot$ M. Namık Yalçın ${ }^{4}$ - Volker Wilde $^{5}$. \\ Eberhard Schindler $^{5} \cdot$ Peter Königshof ${ }^{5}$ (D) Emine Şeker Zor ${ }^{1}$ (D) $\cdot$ Achim Wehrmann ${ }^{6}$
}

Published online: 3 November 2018

(C) Senckenberg Gesellschaft für Naturforschung and Springer-Verlag GmbH Germany, part of Springer Nature 2018

\section{Correction to: Palaeobio Palaeoenv https://doi.org/10.1007/s12549-018-0340-5}

There is a mistake in the caption of Fig. $8 \mathrm{~m}$. It should be "Svantovites lethiersi Casier, 1979" instead of "Svantovites lethiersi Becker 1971".

The online version of the original article can be found at https://doi.org/ 10.1007/s12549-018-0340-5

Atike Nazik

anazik@cu.edu.tr

Helga Groos-Uffenorde

hgroos@gwdg.de

Ewa Olempska

olempska@twarda.pan.pl

M. Namık Yalçın

mny@ istanbul.edu.tr

Volker Wilde

Volker.Wilde@senckenberg.de

Eberhard Schindler

eberhard.schindler@senckenberg.de

Peter Königshof

Peter.Koenigshof@senckenberg.de

Emine Seker Zor

eseker@cu.edu.tr
Achim Wehrmann

achim.wehrmann@senckenberg.de

1 Department of Geological Engineering, Çukurova University, 01330 Adana, Turkey

2 Geoscience Museum (GZG), University of Göttingen, Goldschmidt-Str. 3, 37077 Göttingen, Germany

3 Institute of Paleobiology, Polish Academy of Sciences, Twarda 51/ 55, 00-818 Warszawa, Poland

4 Engineering Faculty, Department of Geological Engineering, İstanbul University, 34850 Avcılar, İstanbul, Turkey

5 Department of Palaeontology and Historical Geology, Senckenberg Forschungsinstitut und Naturmuseum, Senckenberganlage 25, 60325 Frankfurt am Main, Germany

6 Senckenberg am Meer, Marine Research Department, Südstrand 40, 26382 Wilhelmshaven, Germany 